\title{
The Gift and the Threat: \\ An Artistic Exploration into the Machine's Threat Against the Flesh Body
}

\author{
Laurie Petrou \\ September 13, 2003
}

\section{Abstract:}

This paper acts as a support for the two projects I have submitted: Industrial Strength and The Gift The Threat. The projects and the paper examine ideas of the threat of the metallized body on the flesh body. Aesthetics and texts vitalized ideas that were explored through the videos, and the videos themselves represent an artistic discovery and a contribution to aesthetics, history and philosophy - as well as a springboard for a larger body of work. My research involved analysis of the fascists and the Futurists and their use of the machine and machine-body ideals, the cult of the engineer, rhetorical applications of the Mechtech machine as determined by Barry Brummett as well as examination into texts and imagery involving the body, dance, military aesthetics and finally, much personal discovery.

The process of making the two videos revealed my own position on the topic of the body - filming my own body in relation to texts and imagery analyzed, I was forced to answer questions of how I felt about the body, technology, spirituality and art making, all within an academic and artistic context.

The footage and soundtrack in both videos are original (save for one still image) and were composed using a process that I explore at length in the paper: spiritual and highly personal, the process divulges much about the artist, and likewise, I hope that the reading of the projects offers discovery for the viewer in the form of personal questions of the body and the machine.

The possibility for further artistic and academic work on the ideas examined in these projects is exciting: my focus was solely on the Mechtech machine (gears and pistons, and what we would know as factory machinery), fascism and the body, but there are many ideas one could expand upon, including a study in gender and machine aesthetics; contemporary machines and the body; and the body and mechanical/flesh motion. My hope is that these projects inspire questions, ideas and further pursuits based on the topics explored within the works and paper.

Student's signature:

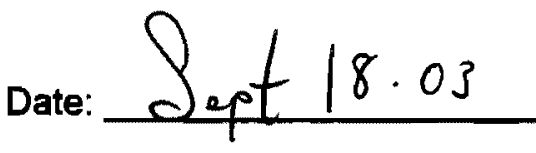


$\underline{\text { Table of Contents }}$

Project Overview__ 1

Mechtech Machines: Examples and Exploration__ 4

The Futurists and The Perfect Man 11

The Cult of the Engineer $\quad 13$

The Making: A Diary___ 15

The Making: Aesthetic and Audio Choices__ 21

Conclusion 28

Bibliography and Filmography___ $\quad 30$

Images Reference ___ 36 
The Gift and the Threat:

An Artistic Exploration into the Machine's Threat Against the Flesh Body

Laurie Petrou

September, 2003

\section{Project Overview}

When I manage to closely track my own being I become aware of my own conditioned inclination to separate in reaction to the multitude (and the subtlest) of occurrences that are present moment to moment. I'm not alone in this, for when observing others closely I experience most others as being sirnilarly conditioned and as behaving quite like me. Our conditioning is so strong that I see no alternative but to engage the practice of processes that provide the means with which to intentionally examine and break whatever habituation we have running us.

\section{- Ada Medina}

"The machine is as old as the wheel, the wings of Icarus or the Trojan horse. But it [...] has transcended its utilitarian functions and acquired a variety of meanings, aesthetic and philosophical, which are only distantly related to its practical uses."

- John Baur

"Aesthetics get perverted, of course, when used irresponsibly, when misused by power."

\section{- Ada Medina}

The purpose of this paper is to provide support to the two videos submitted as my project work. It endeavors to offer exploration and discussion of the ideas that influenced and vitalized my artistic pieces and the process of making said pieces. I have chosen to write in an informal voice rather than a formal or more discursive one: I feel this allows for more honesty in revealing my position as a maker, and situates me and the viewer closer to the art pieces and process. 
The process of making these pieces was intertwined with early imagery, aesthetics and questions that at first were not sharply articulated. These questions led to choices in making, research, and finally much personal discovery. I have determined these roughly as follows. Initially I was curious and attracted to imagery of soft bodies and, in contrast, of sharp and mechanical shapes as taking on a rather angry or violent persona. I began to wonder how bodies themselves responded under the surge of large, imposing machinery. This led me to the luddites and the destruction of machines by bodies, which itself offered a series of images and aesthetic possibilities. I began to wonder what, if any, group might take the imposing and violent persona of the machine (and here I mean the Mechtech machine as defined by Barry Brummett: gears and pistons, large, clean steel) and use it towards their ideologies. I was led to the fascists and Futurists and their 'pure, strong' body ideals as related to the machine. Then I began making: my process is one in which I allow my senses to take precedence and the exploration to evolve afterward. The process of making the two videos Industrial Strength and The Gift The Threat, shall be addressed in this support paper. It involved a great deal of personal discovery, resistance, and was influenced by history, theorists, art and artists, whose contribution and influence will be discussed here.

These pieces are as much about discovery and exploration as they are artistic statements. I acknowledge the potential for more exploration of the ideas that influenced these pieces and also the potential for further discovery in the process of 
making itself. In a way, these pieces, while they are resolved and I confidently defend them, are potentially the beginning of a larger body of work and discovery.

I would like to thank Bruce Elder, my advisor, for his dedication and commitment to his students and to academia and aesthetics; I am certain I would not have been able to arrive at the completion of these projects without his assistance. I also offer my gratitude to Ryerson and York Universities and their faculty for providing a stimulating and exciting program unlike any graduate program I have encountered. Thanks specifically to the members of the faculty who have taken the time to assist me in my project through their position on my committee: Professor Michael Murphy and Professor Seth Feldman.

Thanks to my parents for their unwavering support in the endeavors of their children. This project is dedicated to my brother, Michael, whom I admire so very much. And to my husband, Jay: the love of my life. 


\section{Mechtech Machines: Examples and Exploration}

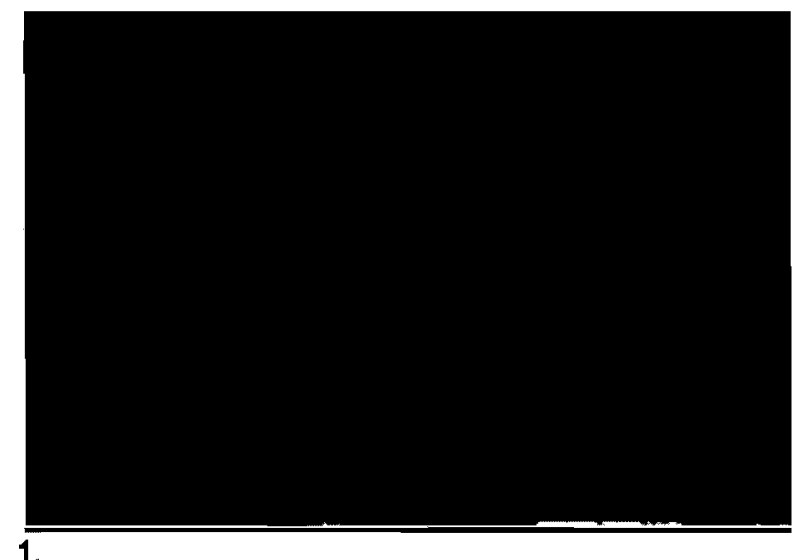

In my research, I explored texts and imagery that divulged the threat of the machine on the flesh-body when used by the fascists or Futurists to further notions of the machine-body among other political ideologies. This is not an examination of machine art or gender studies, but both were influential in the making of these projects. There are many potential directions in which this topic could be expanded. I recognize these and wish to qualify my area of study. With regards to machine imagery, I have examined the machines mainly that fall into the category outlined as 'Mechtech' (Brummett 19) from pre-WWII onwards, as it is a category of machinery that lends itself to aggressive interpretation and fits well with an examination of the threat of the machine on the flesh-body. I analyzed this threat by examining solely the fascist politics of the National Socialists as well as the Futurists and recognize that a wider exploration of other groups would provide worthwhile. Likewise, machinery other than that which I am critiquing - for example, personal computers and more compact and contemporary machines - could prove to be interesting in explorations of technology and power and the impact on the body. 


\section{Mechtech Machines: Examples and Exploration}

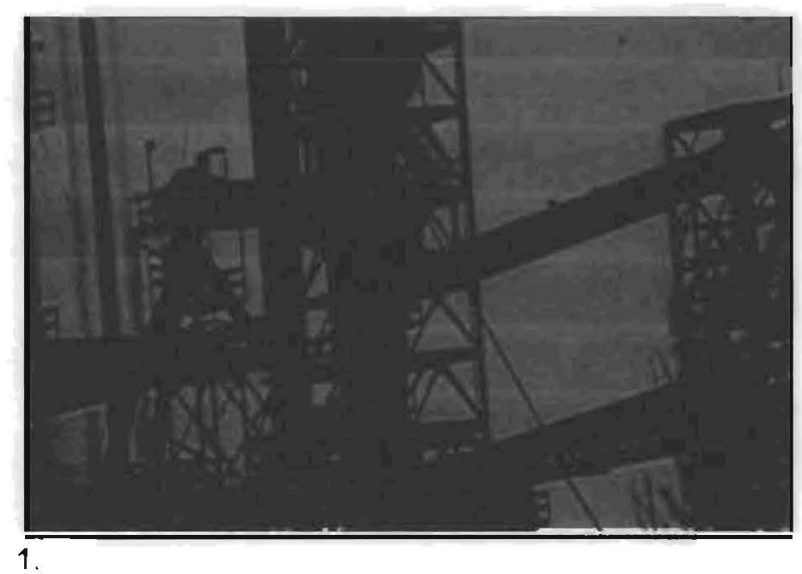

In my research, I explored texts and imagery that divulged the threat of the machine on the flesh-body when used by the fascists or Futurists to further notions of the machine-body among other political ideologies. This is not an examination of machine art or gender studies, but both were influential in the making of these projects. There are many potential directions in which this topic could be expanded. I recognize these and wish to qualify my area of study. With regards to machine imagery, I have examined the machines mainly that fall into the category outlined as 'Mechtech' (Brummett 19) from pre-WWII onwards, as it is a category of machinery that lends itself to aggressive interpretation and fits well with an examination of the threat of the machine on the flesh-body. I analyzed this threat by examining solely the fascist politics of the National Socialists as well as the Futurists and recognize that a wider exploration of other groups would provide worthwhile. Likewise, machinery other than that which I am critiquing - for example, personal computers and more compact and contemporary machines - could prove to be interesting in explorations of technology and power and the impact on the body. 
My research and exploration into ideas of the body stemmed as much from the process of making as from the influence of other makers - by filming my body I discovered a wide range of reactions and emotions towards the body, and these became intertwined with responses to the Mechtech machine as it could be abused by power. The process of making suggests the bulk of my ideas on the flesh body, and they will be discussed at length further on.

My approach to research has been through analysis of text, imagery, film and signs of both fascist and machine/engineering aesthetics as well as those of the body. Given the narrow focus of my project, I critiqued the work of Sigurdur Gylfi Magnússon (2003) in reference to the archival research method, whose work suggests that historical research can benefit from isolation from a larger historical context. He discusses the scholarly trends in history of using metanarratives within a very large and general historical context, and suggests that this presents a difficulty for the viability of the work in question:

The struggle for historians, whether studying social history, gender history, women's history, gay history, microhistory, or anything else, is in fitting their own research into this particular frame of general history, finding a place for their research within this context. If they fail to do this, their research is likely to be considered flawed and disqualified from a place in general history (703).

I agree with much of what Magnússon suggests particularly as it pertains to historical scholarship in general, but also think that even a large and over simplified context is difficult to isolate oneself from. By this I mean that the making and the reading of a text or work will likely always be influenced by a generally accepted history, or a specific, personal history. Nonetheless, his work has provided an interesting 
perspective and was used in conjunction with other texts on historical research (Schuchard, 2000; Starn, 2002).

I acknowledge that the videos that I have made are personal responses to fascist aesthetics and I by no means mean any disrespect to those who suffered the horror that resulted from these parties. My intention is not to romanticize fascism, but to offer an aesthetic examination and response to ideas and explorations into the threat of the machine-body to the flesh-body.

The texts and imagery dealing with technology and aesthetics that vitalized the projects offered differing perspectives on ideas of the machine, power and the body. I would like to outline these in this paper by way of explaining how some select texts involving fascism, the Futurists, the cult of the engineer, the body and spirituality provided support for the projects, and will then explore the process of making and my personal position on the flesh-body in the section The Making: The Diary. The texts that I analyzed by no means represent the entirety of work on this topic but demonstrate influential ideas that I explored regarding the connection between fascism and the machine aesthetic and ideas based on the machine-body and the flesh-body.

The imagery of machines upon which I focused for this project, as I mentioned, are those that fall into Barry Brummett's category called Mechtech. Brummett has divided machine aesthetics into three categories: Mechtech, Electrotech and Chaotech. Mechtech is the aesthetic that involves what one commonly thinks of when imagining factory machinery: smoke stacks, pistons, gears - large, domineering shapes. Read rhetorically, Mechtech (in Brummett's 
application) can be interpreted via the following categories (other machine aesthetics omitted for this purpose):

As Subject: Rhythmic, patterned

As Commodity/object. Geometric, metal, danger, oiled

Aesthetics of Production: Efficiency, uniformity, perfection

Gender. Male

Persona: Warrior

Dominant Relationship: Violence

Exotic: Body

Motivating Context: The Factory (Brummett 19).

According to Brummett, seeing an object as an aesthetic, meaning reacting

rhetorically or aesthetically to an object, requires a kind of self investment with the object: "It becomes us, and we become a part of it." (19) I find this idea suits an aesthetic approach to the topic; not only does this pose interesting questions as to the nature of the body's link to or threat by the machine, but it also suggests the strong aesthetic experience of art making itself. One's relationship with one's work artistically acts out Brummett's claim that 'it becomes us and we become a part of it'. He also recognizes the importance of regarding objects aesthetically, but not neglecting their intended purpose - the very function of the machine is not ignored but one is aware of the power it exercises from an aesthetic perspective.

The main source footage used in my projects in the sections dealing with machines reflects the above factors of Mechtech. I chose a majestic, powerful and geometric machine landscape. 


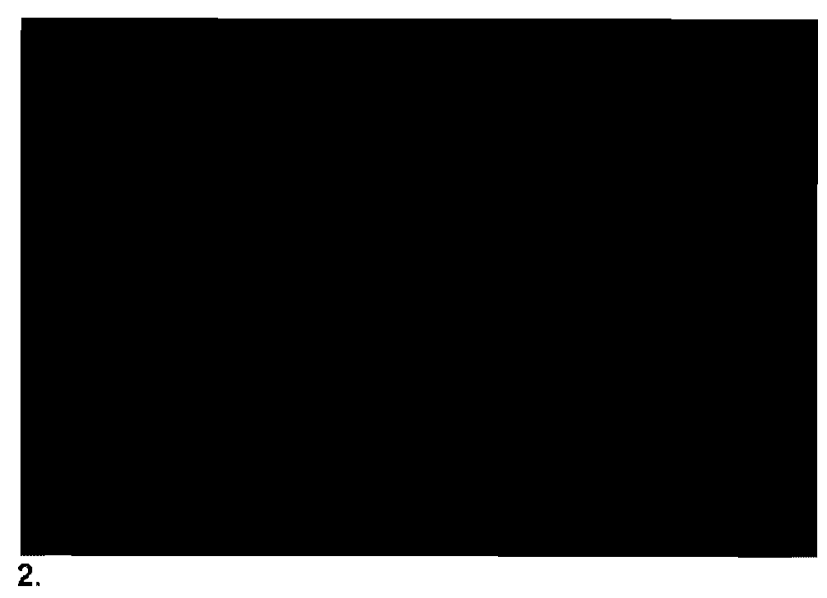

Association in present day with smoke and smokestacks is a reflection of a change in our perception of industry; environmental concerns eclipse our readings of such landscape, our relationship to such shapes. Likewise during other periods (the Nazi reign), the same object was read for its aesthetics and its rhetorical potential. The smokestack was a symbol of health, purity, progress, efficiency: "The smokestacks are burning again!" is the call to action in the Nazi propaganda film "Gestem und Heute: Yesterday and Today". In this film, pre-National Socialist Germany is depicted through images of old, broken down machinery (what Brummett calls Chaotech), rot and futility. The smokestacks are meant to reflect the 'New Germany' in their strength and power.

In a speech to the Nazi Youths, Hitler calls for the ideal body: "In our eyes, the German boy of the future must be slim and slender, as fast as a greyhound, tough as leather and hard as Krupp steel." In the first video, Industrial Strength, I incorporated the body as a means of drawing the connections between the aesthetics of Mechtech and how the fascists viewed the body. As an expository essay, this video demonstrates how power uses the machine to pervert the body into the body ideal. In my second video, The Gift The Threat, I used the body as a sharp contrast to both 


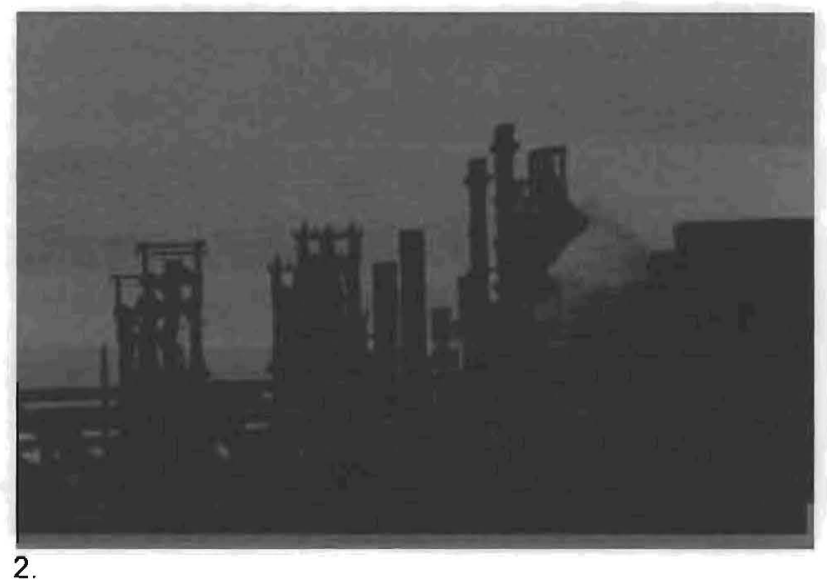

Association in present day with smoke and smokestacks is a reflection of a change in our perception of industry; environmental concerns eclipse our readings of such landscape, our relationship to such shapes. Likewise during other periods (the Nazi reign), the same object was read for its aesthetics and its rhetorical potential. The smokestack was a symbol of health, purity, progress, efficiency: "The smokestacks are burning again!" is the call to action in the Nazi propaganda film "Gestern und Heute: Yesterday and Today". In this film, pre-National Socialist Germany is depicted through images of old, broken down machinery (what Brummett calls Chaotech), rot and futility. The smokestacks are meant to reflect the 'New Germany' in their strength and power.

In a speech to the Nazi Youths, Hitler calls for the ideal body: "In our eyes, the German boy of the future must be slim and slender, as fast as a greyhound, tough as leather and hard as Krupp steel." In the first video, Industrial Strength, I incorporated the body as a means of drawing the connections between the aesthetics of Mechtech and how the fascists viewed the body. As an expository essay, this video demonstrates how power uses the machine to pervert the body into the body ideal. In my second video, The Gift The Threat, I used the body as a sharp contrast to both 
the machine and the fascist view of the body. Here the body is represented as flesh: soft, undulating, and imperfect.

While all the imagery I used in my projects is my own (save one still image in Industrial Strength), in the course of my research, I discovered a number of source images that reflect the connection between the Mechtech machine aesthetic, fascism and the body as it applies to both. Some of these images are as follows:
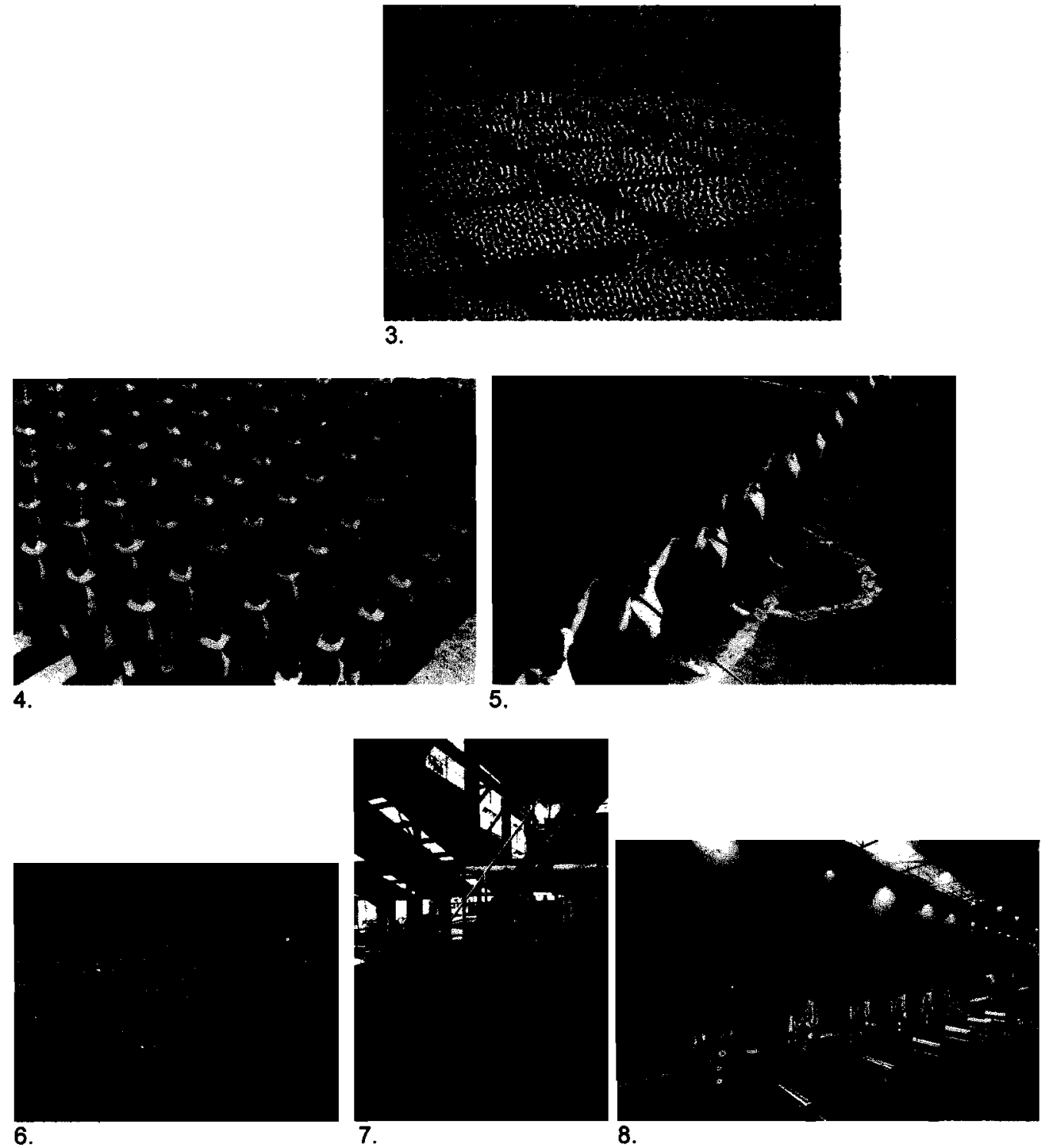
the machine and the fascist view of the body. Here the body is represented as flesh: soft, undulating, and imperfect.

While all the imagery I used in my projects is my own (save one still image in Industrial Strength), in the course of my research, I discovered a number of source images that reflect the connection between the Mechtech machine aesthetic, fascism and the body as it applies to both. Some of these images are as follows:

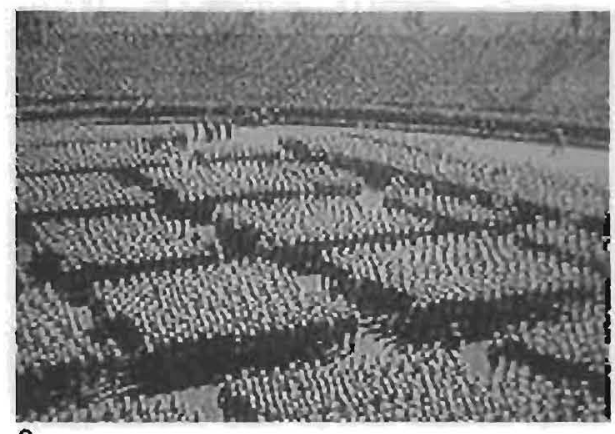

3
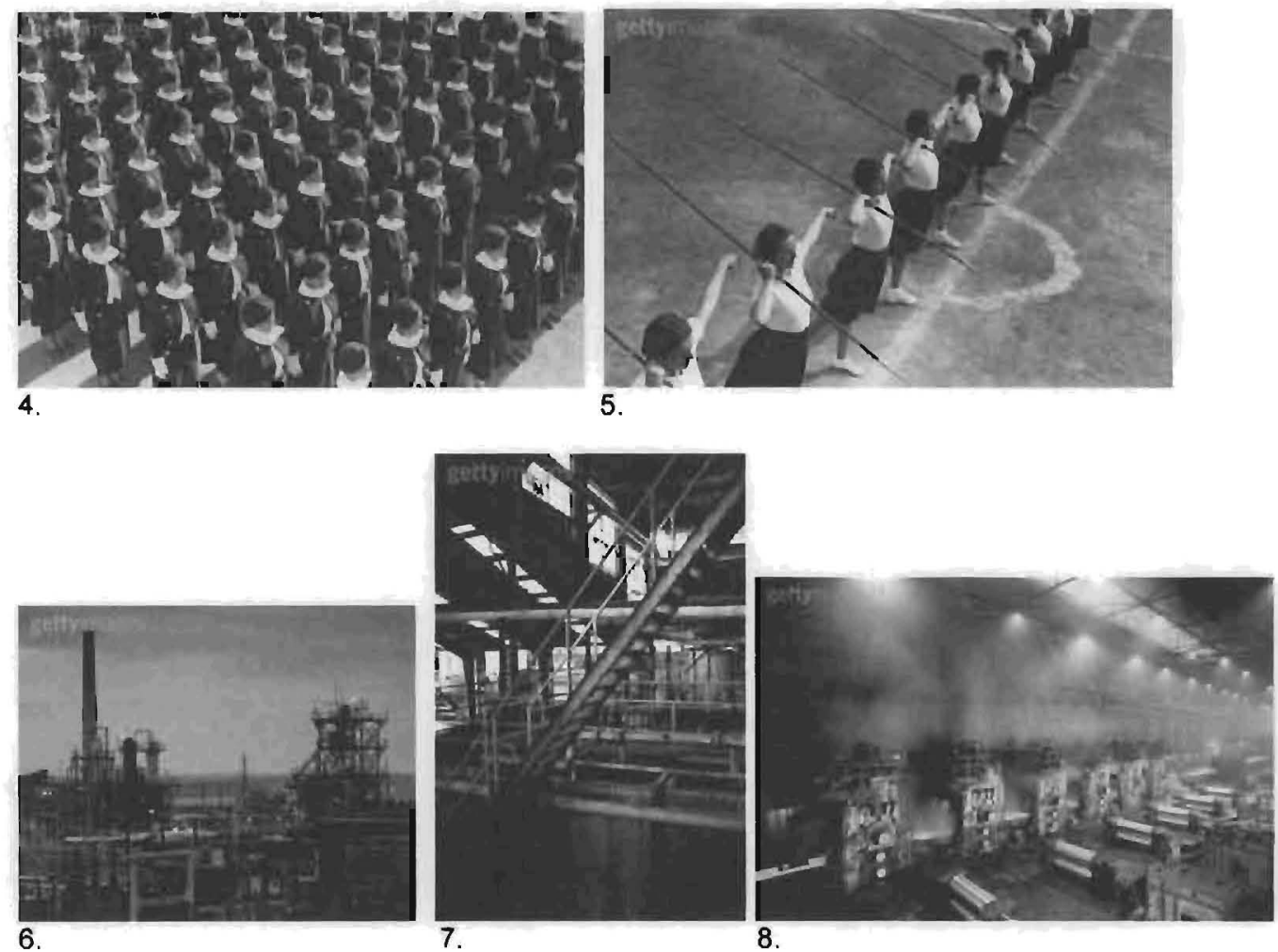

6. 8. 
The connection between fascism and machine aesthetics relates a great deal not only to the aesthetics of the fascists (the army and parade formations, the iconography, the very 'look' of the ideal body), but also in language. A number of examples arose in my research of machinery as a metaphor for the progress, efficiency and power and as the future of the body in the form a metallized body. Further, as per Brummett's contention that it is not only the look of the object but its function, the language used in rhetoric using machine references related both to the look of the machines (i.e. their aesthetics), but also to function, or at least attributes of their functions. Power, violence, speed, efficiency are words often used in relating industry and machinery to fascist politics. Analysis of the fascist fascination with aesthetics reveals an obsession with regulated 'beauty', denoted in the National Socialists desire for regulation of human aesthetics: their genocide of the Jews, the physically different, the old, among others, relates to their desire for the 'pure'. Geometric, regulated, replicable machinery lends itself to this obsession in aesthetics and function. 


\section{The Futurists and The Perfect Man}

We look for the creation of a nonhuman type in whom moral suffering, goodness of heart, affection, and love, those sole corrosive poisons of inexhaustible vital energy, sole interrupters of our powerful bodily electricity, will be abolished... This norhuman and mechanical being, constructed for an omnipresent velocity, will be naturally cruel, omniscient, and combative. (Marinetti 91)

The pursuit of the human manifestation of machine aesthetics is evident in the art and politics of the Futurists, who tended in the early years towards fascism. Exploration of the texts and imagery of this movement proved influential to my position on machine-body relationships and my projects. Filippo Thommaso Marinetti, the Futurist leader and co-writer of the fascist Futurist Manifesto, called for the abolishment of emotion, the aged, suffering to make way for the perfect Future Man. He wrote War, the World's Only Hygiene, which included the section (from which the above quote is derived) "Multiplied Man and the Reign of the Machine", pledging the commitment to a new human in the age of machines. Their focus on speed, violence and the factory recalls machine aesthetics, movement and sound. In a preface to the Futurist Manifesto, Marinetti states, "Then, face hidden by the good factory slime, covered by metal dross, by useless sweat and heavenly soot, $[. .$.$] we$ dictated our first wills to all the living men on earth," (Marinetti 2). In addition to emotions and age, they rejected feminism and woman in general, as discussed in Anja Klock's "Of Cyborg Technologies and Fascistized Mermaids: Giannina Censi's Aerodanze in 1930s Italy" (1999), and Christine Poggi's "Dreams of Metallized Flesh: Futurism and the Masculine Body". 
I chose not to explore the art of the Futurists at length in this paper, but it bears mentioning that most Futurist art and poetry reflected the artists' fascination with machines and a distain for pastoral landscapes. The body was rejected as a vessel of desire, but as Poggi points out, there is a dichotomy between the Futurists' rejection of the flesh-body and a desire for a virile, metallized future body:

How best to affirm virility while becoming free of the debilitating effects of desire? How to imagine the body's boundaries-as both permeable, shifting, and open to fusion with the environment, and as rigid, closed, and resistant to penetration? How to hold in solution a narcissistic longing for expansion of the ego and fantasies of omnipotence, with their seeming negation, a longing to overcome subject/object distinctions in a corporeal fusion with matter/mother? How to respond to the body's temporality, its inevitable mortality, and reversion to (mere) matter? And finally, how to create (and believe in) an immortal man/machine hybrid, a body always already posited in the future tense? (20)

The film Architecture of Doom acknowledges the preoccupation with machine and industrial aesthetics (namely regularity, geometry and marks of the Bauhaus and other architectural movements) and how they arguably precipitated fascism. Hitler is explored as a failed artist with a great love of the arts and aesthetics, spearheading the design of the Nazi aesthetic, much of which bears resemblance to industry. But as I stated, I did not endeavor to examine existing aesthetics associated with fascism, but rather chose to explore the aesthetics of machinery as they pertained to and were used by the fascists by application of their body-ideal. 


\section{The Cult of the Engineer}

The figure of the hero-engineer, however, charged through popular fiction and advertisements with a panache that led the eye away from the grimness of scientifically managed industrial servitude.

(Stockton 3)

...the $[\ldots]$ rhetoric of the heroic engineer is, in some ways, the rhetoric of the fascist hero, with the same tendency to paste over the rift between nature and technology, expression and production, vision and violence.

(Stockton 5)

Exploring machine aesthetics and their connection to power led me to research design, and whether there was a link between industrial design and an interpretation of power connected to the Mechtech machine. I was curious as to whether power, aggression or any of the marks evident in appropriating machine aesthetics was present at the design stage. Sharon Stockton's article "Engineering Power: Hoover, Rand, Pound, and the Heroic Architect" (2001) provided interesting insight, exploring the status of the engineer or architect in war-time America, and the links to fascism: "as Germans and Italians worshipped the charismatic leader, we pushed to the top of the world's economic order through the technological application of visionary science." (Stockton 1). She discusses the rise of the 'hero-engineer' and the strive for efficiency and regularity from a political position - meaning the desire to use technology and 'progress' to advance civilization - that persisted in industrial and architectural design. Considered leaders, engineers were influential and, she argues, similar to fascist leaders in their positions in hierarchy. Hoover claimed that the engineer maintained an elevated position in civilization and in 1939 lauded the 
'goodness' that was the result of their work: "This "goodness," he contends, is the pure and undiluted panacea for whatever ails humankind at any given point in history." (Stockton 6). In this way, the American cult of the engineer didn't simply use the objects themselves as metaphors for politics, but the individuals, and individualism involved in the very making of the objects represented a goal of 'purity' that reflects some of the fascist tendencies toward technology and machinery as well as purity of the body in the fascist body ideal. 


\section{The Making: A Diary}

Through the process of making I explored ideas and opinions inspired by the texts and imagery I analyzed, revealing much to me about my feelings toward the body and the impact of technology on the body. Having explored the body-ideal of the fascists and Futurists, it was an integral experience to discover my own reactions to the body in the process of making the projects.

My first project (Industrial Strength) reacts to my analysis of the connection between the machine and the fascist body-ideal, and yielded a work that recalled the very power politics that I examined: my video appeared more like a piece done in the style of the artists who hailed the machine-body as a celebrated possibility. The body appeared as the metallized body of the Futurists, alongside geometric machines and landscapes. Indeed, this is was what I was trying to display - how the futurists/fascists had viewed the machine and the body as the future evolution of their politics, and also to prove that the connection existed. But the result was a piece that appeared to reveal more about the artist than the research, and begged the question of why I had taken that route. I certainly do not agree with the machine-body politic, but was, and am, fascinated by the history of the use of the machine in politics, power and art: what is it about functional industry that makes it so appealing as for parties such as the fascists? What are the implications of this on the flesh-body?

After completing my first video and discovering how like a fascist art piece it appeared, I began a process of self-reflection to reexamine how I felt ethically, spiritually and artistically about the relationship between the machine and body. 
My response to questions of the body and the machine - questions of ethics, sensuality, power, religion - yielded a resistance. By this I mean that I felt that this was not the place for personal feelings toward the body: that academia didn't require or desire the answers to questions of one's feelings toward the body. And at first, this is what it was: the body, as it is often regarded in artistic and academic circles. In Industrial Strength, the imagery of the body is just that: it's not really mine (by which I mean the way it was artistically and academically regarded). But in the making of The Gift The Threat, I was forced by my desire to answer the abovementioned questions to confront how my body felt in the process of art making. If the Mechtech machine poses a threat to the flesh body, what is the flesh body to me? How does it feel and why should that be preserved? The responses were discovered during the making itself and in working with the imagery afterward.

What I felt toward the body was mostly in a word, comfort. my body as a soft, warm, comfort; as an imperfect, but endearingly imperfect reflection of desire, love, but also (and again, endearingly so) of embarrassment, or rather of blushing - of the subtleties of the human nature.

Essentially, the response was that the body is a gift. This begs the question, 'a gift from whom?' bringing up issues of religion, or l'd prefer, of spirituality. And I feel that not only does the body confront the issue of spirituality, but so also does the art-making process itself.

I take a passive approach when I work artistically. Ideas develop somewhat peripherally - I worry if I concentrate too directly, they will dissolve or become something too crystallized or cartoonish. Working this way allows the piece to arrive 
at its potential. Prior to this work, I often found myself saying that I didn't have a process, that I was strictly concerned with the final aesthetic beauty of the work, until a friend pointed out that this is my process: it isn't conceptual, it is aesthetic. This, I believe is spiritual: it is the quiet process of allowing the truth and honesty in the art arrive without pressure. As artist Ada Medina states of her process and her pieces, "To strive for them (as if they were "achievable" trophies) renders them static and gives them an ideological cast." (15) She also speaks of the somewhat Buddhist nature of the art-making process:

... it involves readjusting my habituated relationship to thinking and to knowing. If the work is to be fresh, and if it's to be a real offering to self and others, it's essential that I activate my surprise, my unfamiliar and unknown throughout the working process. (20)

This acknowledges the spirituality in the process of making, which I feel strongly about, but it still leaves the question of the spirituality of the body - its giftlike natıre and its position in relation to the Mechtech machine. It is my feelings for this issue that I was resistant to search out: why did I find the body to be a gift? I certainly don't have a fundamentalist Christian approach to the body as a gift that is not ours to do with as we will. I believe that our bodies are ours to explore and also to abuse. But why do I continue to return to the word gift as a description of the body? Following the September $11^{\text {th }}$ attacks, there was a panel discussion in New York with Alison Knowles, Eleanor Heartney, Meredith Monk, Linda Montano, and Erik Ehn, moderated by Bonnie Marranca on the topic of Art as Spiritual Practice. Eleanor Heartney discussed an interesting phenomena of artists who have been raised Catholic (or Jewish or Protestant) and while the artists may not as adults 
subscribe to the doctrine, there is an attraction to many aspects in aesthetics or spirituality that resemble the religion they were raised with. In the case of

Catholicism, she discusses the emphasis on the physical body, ritual and beauty, and how (she has noticed) many artists who 'got in trouble with the religious right' came from a Catholic background. She calls these religious rumblings in the rninds of artists the 'Catholic Imagination':

One of the things that is important in thinking about such a thing as a "Catholic imagination" or a "Protestant imagination" or a "Jewish imagination" is that we are not talking about church doctrine or even about people who in their adult lives have a firm belief and devotedly practice their religion. Instead, what interests me is the way in which someone who is raised Catholic or in a very Catholic milieu gets imprinted with this view of the world, so that no matter what happens it becomes a very important part of how they thirik about reality.(22)

I found this interesting because of the role that the religious or spiritual plays and has played in my life. My family is very involved in the Presbyterian Church. My father sings in the choir and is on the board of managers; my brother and I attended Sunday school as children; I was married in our family church. Over years of attending a place that had become one of family, friends and community, spirituality and the Presbyterian doctrine changed for me to be less about the 'religious', and more about, again, comfort. In this way, I feel that the body is a gift of the divine, but also a gift that is ours with 'no strings attached'. This independence and liberalism recalls my feminist leanings and my early studies in feminist art. But like Heartney says, my history of religion and ritual (and for me, this is the ritual of commurity and 
family) has imparted upon me a lingering spirituality and influences my thoughts on the body.

During my textual and imagery analysis, I examined current trends in machinebody movements and used the information I gleaned from this research toward my projects. What was fascinating for me was the clear lack of emotions such as those that I have just described: sentiments such as comfort or tenderness, spirituality or religion are unimportant in a way that recollects the Futurist movement. The human/machine aesthetic has remained strong beyond the historical, and beyond the Mechtech aesthetic. Artists such as Stelarc and Mark Pauline have integrated machines so seamlessly in their work in order that one should wonder what human purpose remains. Stelarc questions the necessity for the very 'essentials' such as skin and organs, replacing the body with machine parts and pushing the limits of body function. His work exacts for me a contemporary example of the trend towards the machine-body, reminiscent of the move toward the Perfect Future Man by the Futurists and the fascists. Mark Pauline heads Survival Research Labs in San Francisco ("Producing the most dangerous shows on Earth"), a collective whose objective involves using military, industrial, electrical machines and creating larger, louder, more dangerous machines using the parts. Their work also involves a function-heavy appropriation of machinery, but with gorilla-like approaches that recall the Futurists' call for the perfect man. Known for stealing factory machinery to suit their needs, SRL created a group of warring robots: violet, strong machines devoid of 
any 'user-friendly' or sentimental characteristics, reminiscent of Marinetti's Futurist Manifesto. These are machines as warriors, similar to Hitler's warriors as machines. 


\section{The Making: Aesthetic and Audio Choices}

In Industrial Strength, I endeavored to link the body and the machine, demonstrating the relationship between the two in a fluid manner, recalling the objectives that emerged through my research to emulate the machine - through the Nazis and the Futurists, namely, and also to allude to the notion that this relationship and an attraction to machine aesthetics is a current as well as historical phenomena.

In The Gift The Threat, as I mentioned earlier, I used the body as a contrast to the machine. The purpose was to demonstrate the vulnerability of the body and the threat that the connection of the machine-body and power poses to the notion of the flesh body as a gift. The Futurists despised all things that involved unruly nature, and femininity (which they saw as inherently liriked) (Poggi 24). Using my own body in the video, in conjunction with the natural sounds of birds and the white noise of the body being filmed provide a contrast to the objectives of the fascists and the Futurists to make the body more machine-like.

I used language in The Gift The Threat both to add a voice to the body and to acknowledge the role of language in the machine-power equation. Much of my research of speeches and manifestos revealed that the connection between machines and fascism/power went beyond aesthetics. Metaphor was a tool used a great deal by the fascists and Futurists, and many body-machine allusions were drawn through language. In Poetry as Prosthesis Brian McHale discusses the trend of machine metaphor in poetry and discusses the notion that language itself is prosthesis, or a machine-like extension of the body. He also suggests the alternative, 
Unless, of course, this is all simply mistaken.

According to the maverick linguistic theorist and historian

Roy Harris (1987), the notion that language is a machine-

whether internalized as cognitive machinery or externalized

as the system of la langue - is a case of our allowing ourselves to be victimized by our own metaphors. In Harris's iconoclastic view, language is nothing at all like a machine it is, rather, a social behavior integral to other social behaviors [...] "Language is a prosthesis" is, in this view, nothing but pernicious mystification (29)

\section{Sound}

The sound for the project was mostly done after the visual was completed, but some of it I developed in Professor Murphy's Technology class prior to completion. This is the last two minutes or so of the video, and was manipulated to fit with the visual. All the sounds are from industrial and military tracks from the audio library at the Rogers building. I combined them in the sound program Nuendo and lay them on top of the visuals.

For Industrial Strength, I wanted to start with something quite ambient, but then bring in sounds that were more erratic and grinding for the introduction of the body to the piece. I lay the harp-tuning sounds on top of these industrial noises because I think they suggest both industry but also something more natural and soft - they exact the tension between the body and machine. Further along, I used a rough, static sound that I thought went well with the choppy, shaky visuals, and then mixed in some marching sounds (from a Nazi march). When the footage changed to faster, more fluid pans, I wanted a quick, haunted sound to signify the change, and then again used some ambient noise. The sequence with the close-up drill demanded sound that appeared to be building up, so I used the same sequence as 
at the begirnning (when the body appeared). A lot of ambient and military noises (the machines and the marches sound so similar due to the rhythm and the material) and then I incorporated the sound l'd developed in Professor Murphy's class - air raid sirens mixed with ban saw noise, then marching, and ending with small then large explosions that then turn to harnmering. The very last 'boom' was used as the ending because it seems to brush the visual from the frame.

For The Gift The Threat, I used much of the abovementioned machine and military sounds, but also incorporated a segment of natural sounds to go with the body. These include bird chirps, some of which were stretched out to give a more indistinguishable echo.

As evidenced here, the sound was somewhat predetermined because it depended on the visuals. Still, I only marked out major time changes before working on the sound and did not use the visuals while developing it. I think if I had it might have seemed contrived.

\section{Footage}
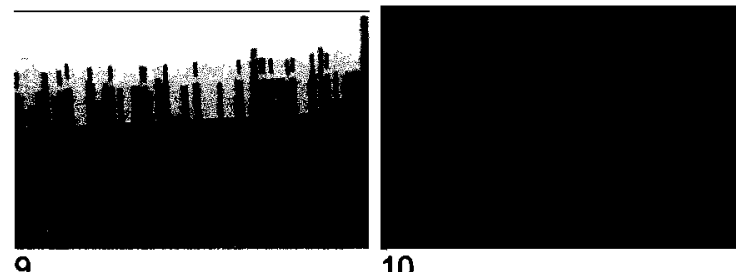
10.
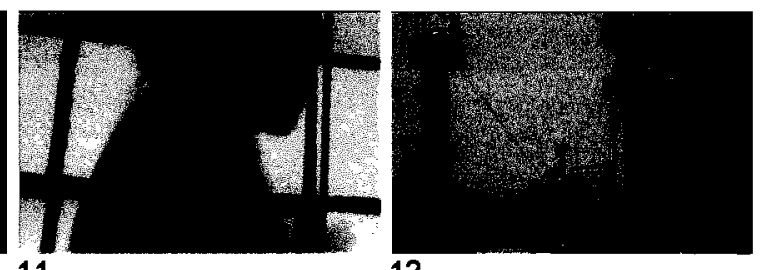

12.

The imagery I used came for the most part from self-shot body footage and footage I took of the Hamilton industrial skyline. In addition to this, I shot a number of mechanical gears and construction machinery. Finally, for Industrial Strength I used one still stock image from Gettyone.com (a stock imagery site), demonstrating a crowd of Nazi youth. 
at the beginning (when the body appeared). A lot of ambient and military noises (the machines and the marches sound so similar due to the rhythm and the material) and then I incorporated the sound l'd developed in Professor Murphy's class - air raid sirens mixed with ban saw noise, then marching, and ending with small then large explosions that then turn to hammering. The very last 'boom' was used as the ending because it seems to brush the visual from the frame.

For The Gift The Threat, I used much of the abovementioned machine and military sounds, but also incorporated a segment of natural sounds to go with the body. These include bird chirps, some of which were stretched out to give a more indistinguishable echo.

As evidenced here, the sound was somewhat predetermined because it depended on the visuals. Still, I only marked out major time changes before working on the sound and did not use the visuals while developing it. I think if I had it might have seemed contrived.

\section{Footage}

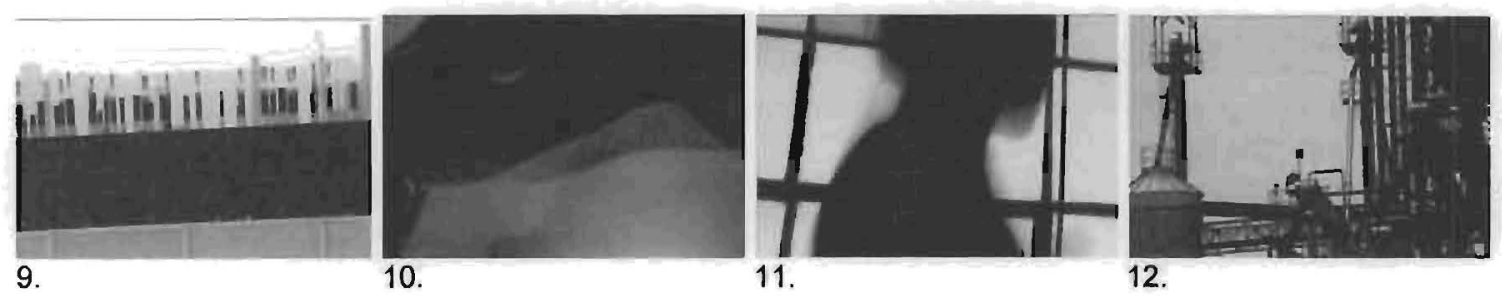

The imagery I used came for the most part from self-shot body footage and footage I took of the Hamilton industrial skyline. In addition to this, I shot a number of mechanical gears and construction machinery. Finally, for Industrial Strength I used one still stock image from Gettyone.com (a stock imagery site), demonstrating a crowd of Nazi youth. 
The approach to The Gift The Threat was one of contrast. I wanted the pace, the colours, the sounds and the imagery to suggest that the machine and the machine-body ideology threatened the notion of the body as an imperfect gift.

For Industrial Strength, the piece became broken down into parts: the pale, then orange and red early stages, the body, the faster sections, those that seem more aggressive or rhythmic, and finally the pale, ephemeral ending which I equate to a kind of redemption sequence in colour, speed, focus and sound.

My choices of colours and layers were based on the desire to evoke a mood and complexity that was lacking in the original footage. Further, some of the clips are slowed up to $900 \%$ their original speed to draw out particular segments. This manipulation also lent the pieces a feel reminiscent of archival footage in some sections in the grainy and sometimes flickering style of the piece.

Mindful of my research, I worked in pursuit of an aesthetic that addresses the appeal of machine aesthetics in fascism and Futurism but also in current trends in machine art suggesting a threat to the flesh-body. I reflected upon a great deal of imagery and text during the making of this piece, including weapon design, dance, industrial design, army formations, as well as texts dealing with semiotics such as the work of Roland Barthes. Barthes states in The New Citroen:

\footnotetext{
We must not forget that an object is the best messenger of a world above that of nature: one can easily see in an object at once a perfection and an absence of origin, a closure and a brilliance, a transformation of life into matter (matter is much more magical than life), and in a word a silence which belongs to the realm of fairy-tales. (Barthes 1 )
} 
As responses to the fascist pursuit of a metallized body and to my own feelings towards the preservation of the flesh-body, the pieces offer a new perspective; in Barthes words, they are 'messengers', and 'life into matter'. Barthes contends that matter is more magical than life. This touches on an important element of my project making as well text and imagery analysis: I feel that life is more magical than matter, but am fascinated by the attraction to matter and the magical hold it takes. That a machine (the video camera) was the tool used in response to ideas of the machinebody, and that the threat on the flesh-body was explored by filming a body with a machine was interesting to me. So too was motion: the Futurists were driven by speed and mechanical motion. I wanted to contrast this with the slow and irregular movements of the body in The Gift The Threat. An article by Elizabeth Coffman titled Women in Motion: Loie Fuller and the "Interpenetration" of Art and Science discusses the dancer Loie Fuller and points out that the Futurists praised Fuller as the incarnation of 'metallicity', seeing motion as mechanical rather than natural (75). The movement and pace of the body segments in The Gift The Threat suggest the natural movement of the flesh-body, while in Industrial Strength the body takes on more mechanical or industrial attributes. I think that this exploration offers potential for a further body of work studying the movement and motion of the body.

In conjunction with the experimental pieces I have submitted, I was initially going to create a more linear, narrative piece using archival imagery, machine imagery and text. I decided this was unnecessary, and in fact may have hindered the 
impact of the experimental pieces. However, the imagery proved helpful to my overall research. I have included a segment of those images here:

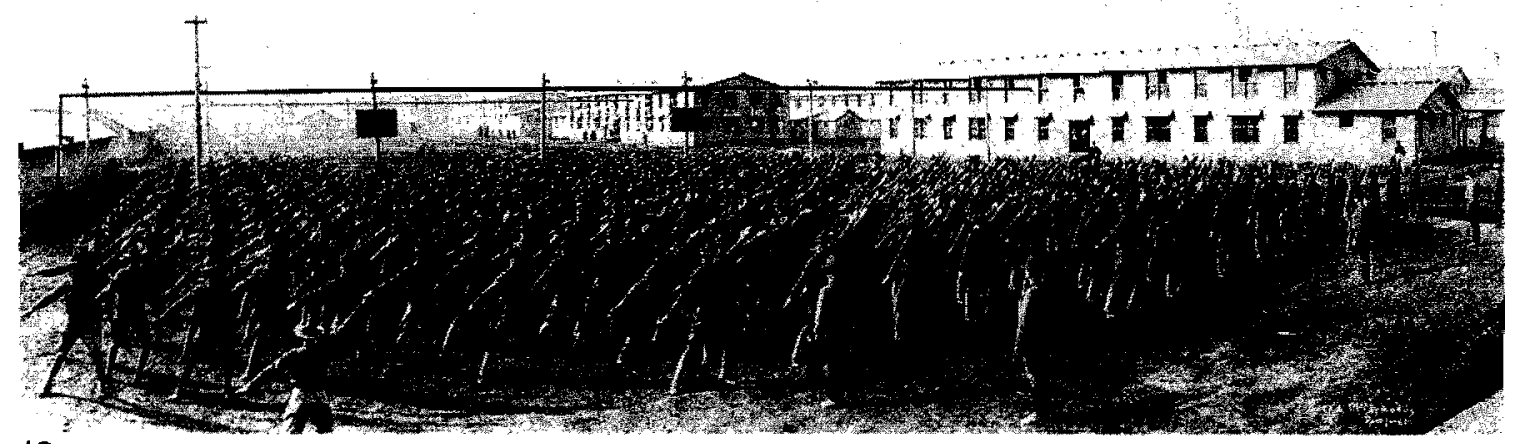

13.

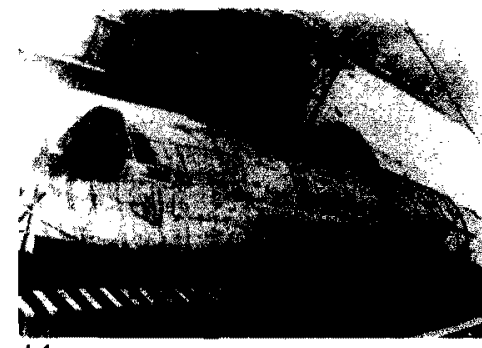

14.
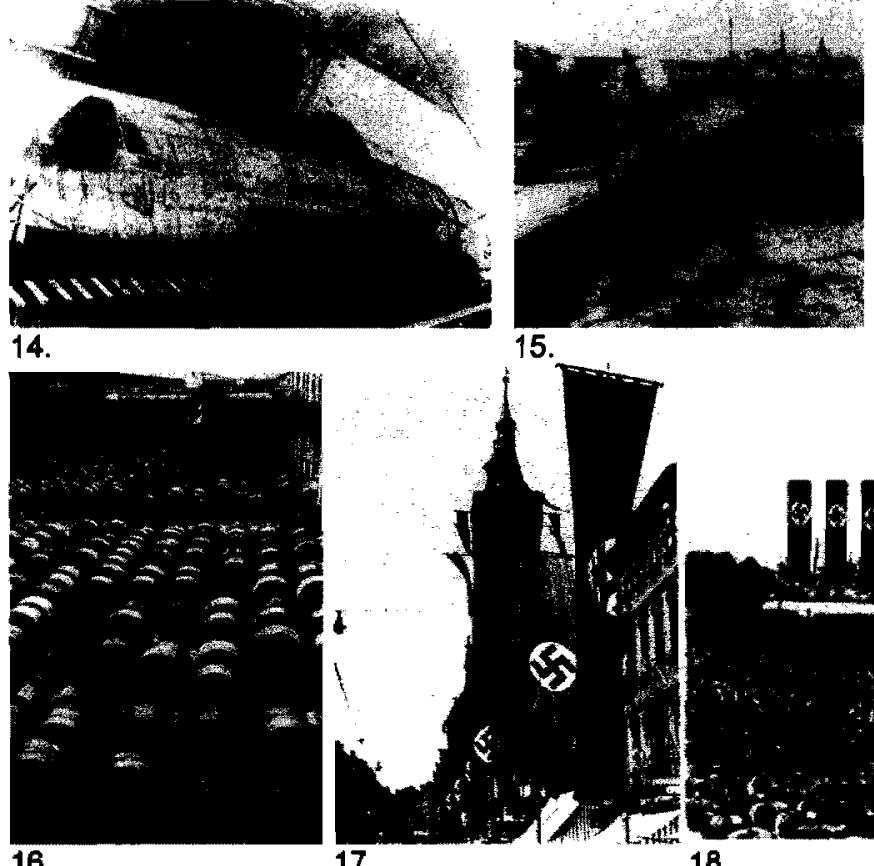

16.

17.

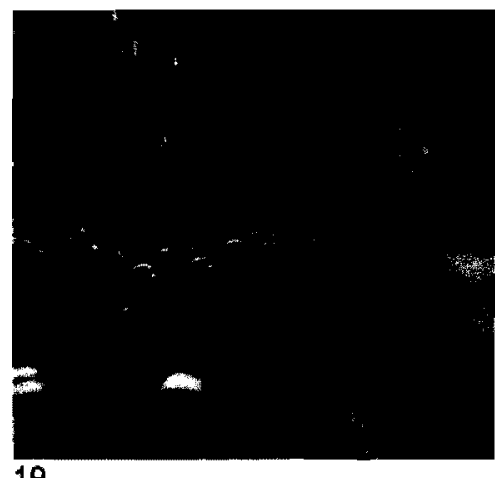

19.
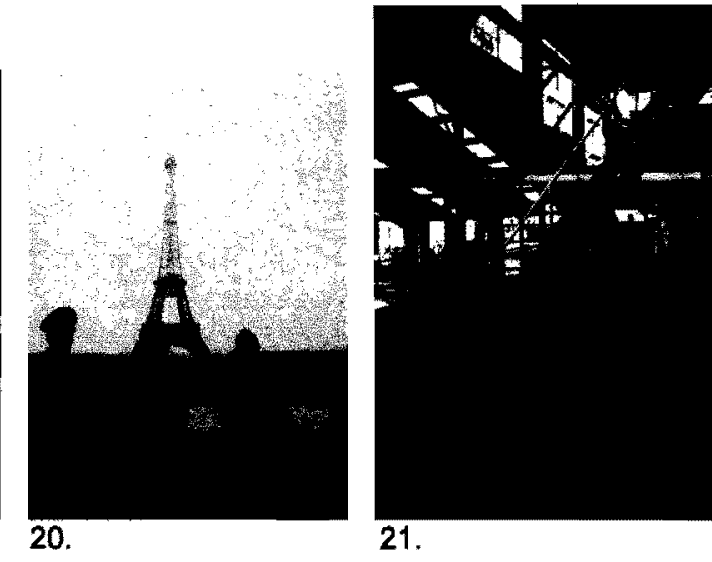
impact of the experimental pieces. However, the imagery proved helpful to my overall research. I have included a segment of those images here:

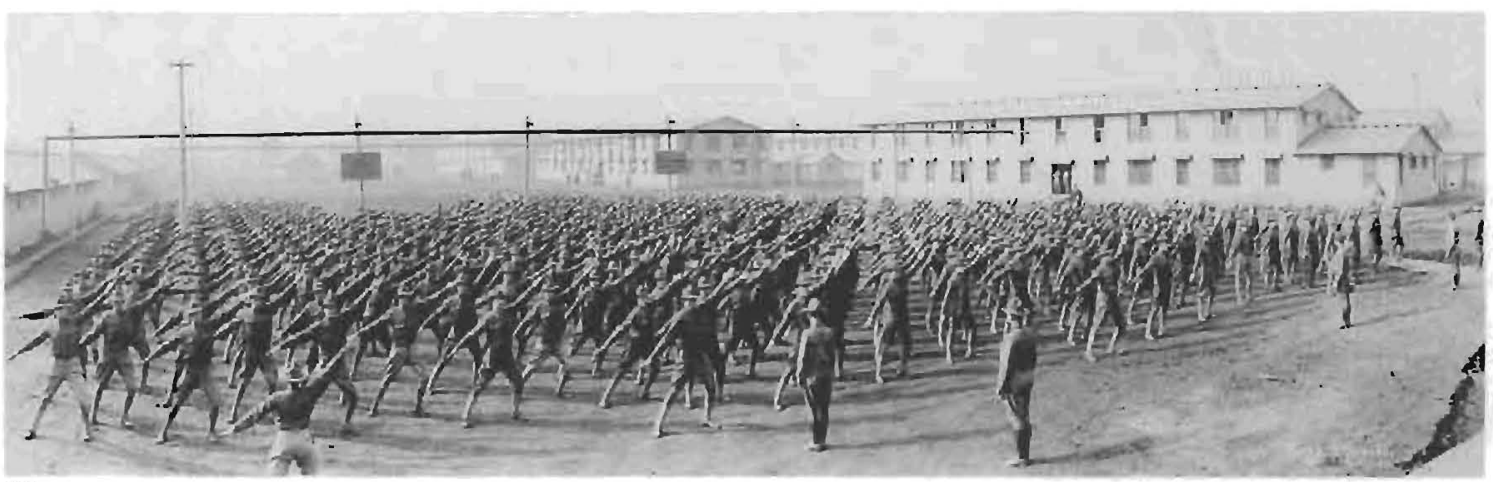

13

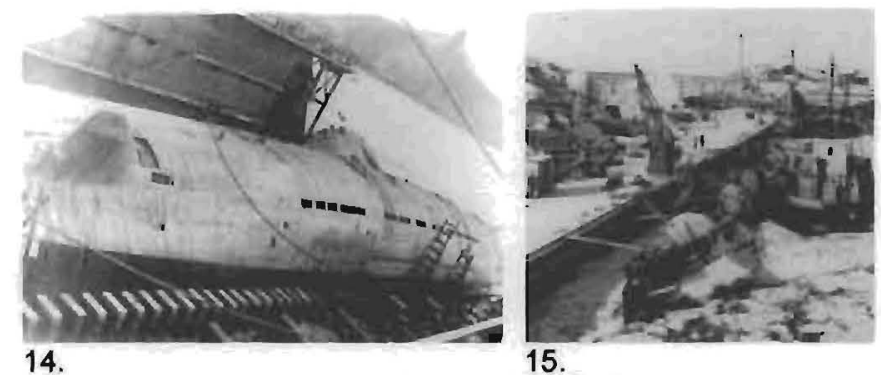

14. 15.

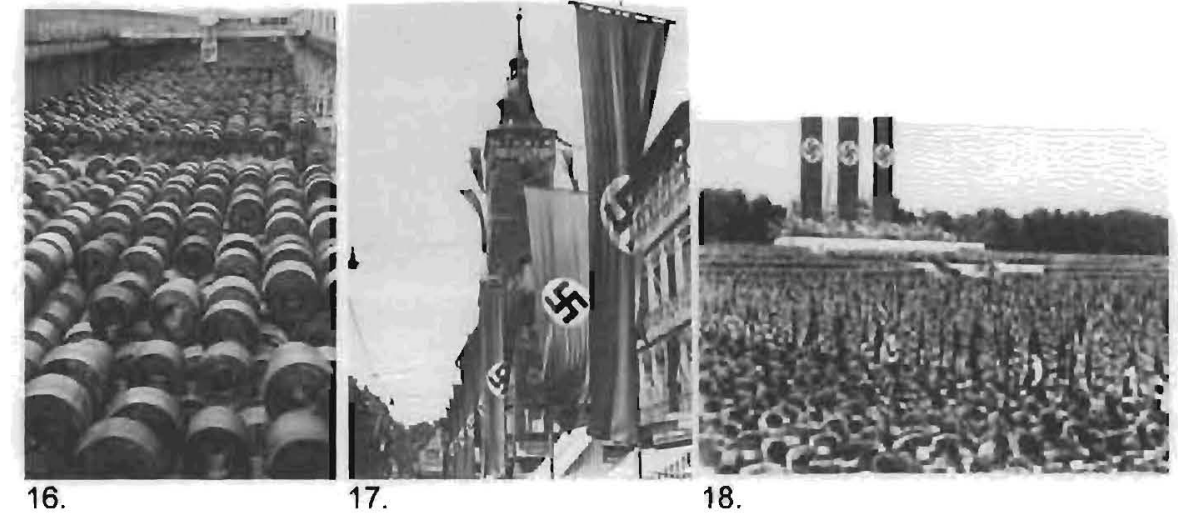

18
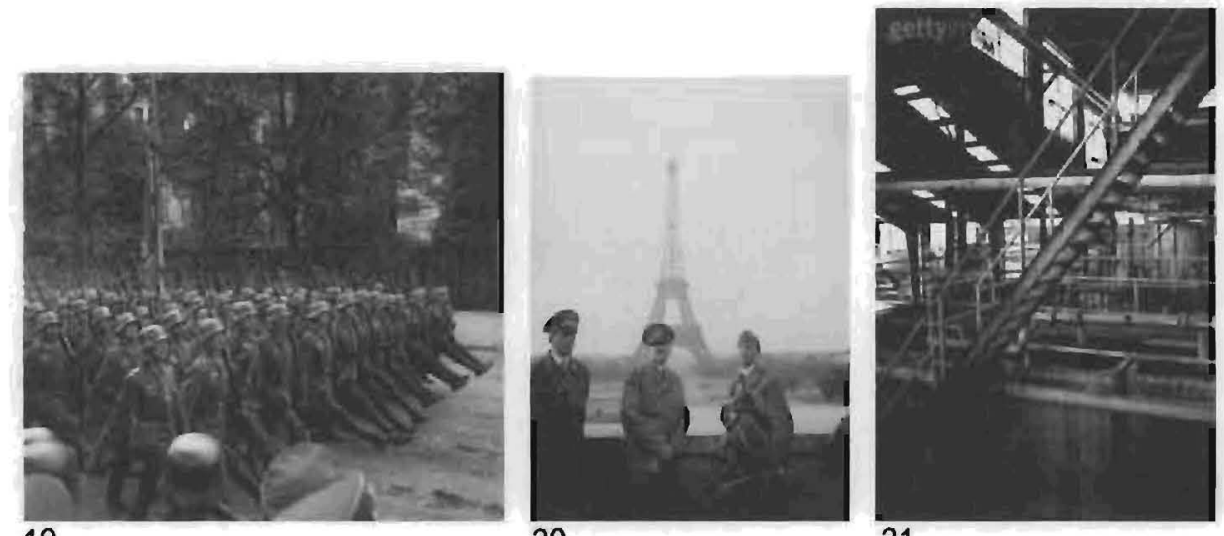

20.

21. 

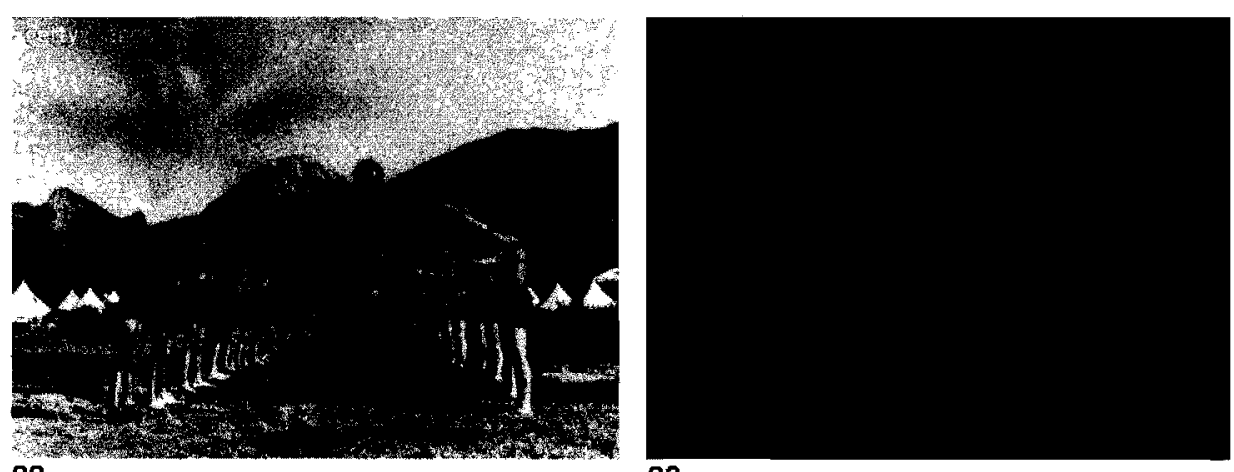

22.

23.

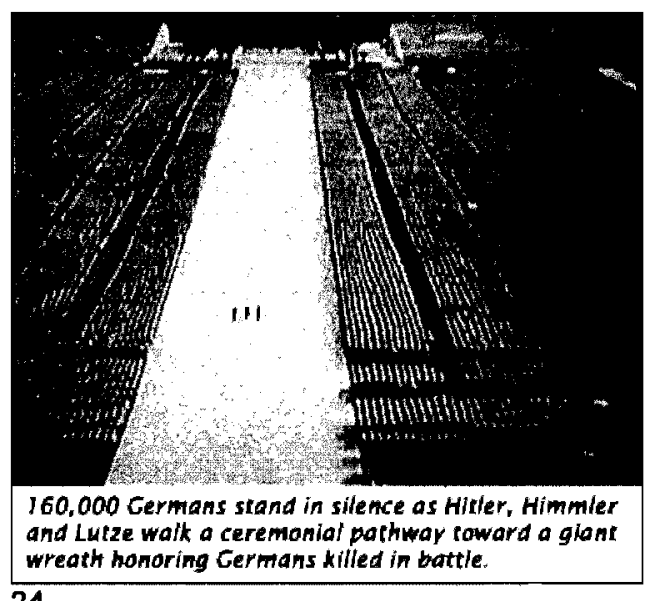

24.

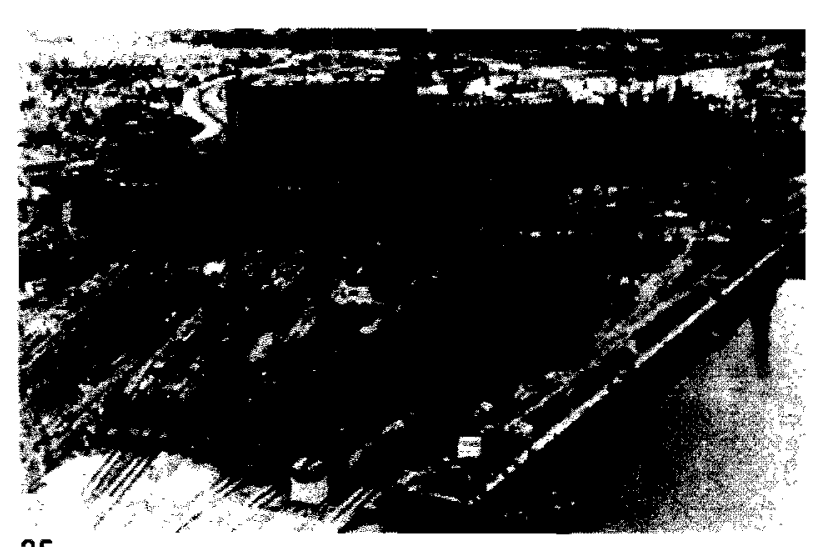

25
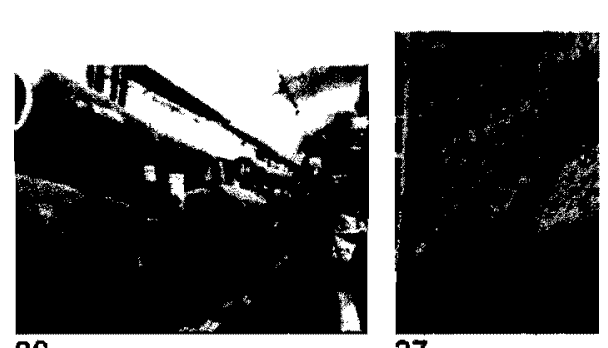

27.

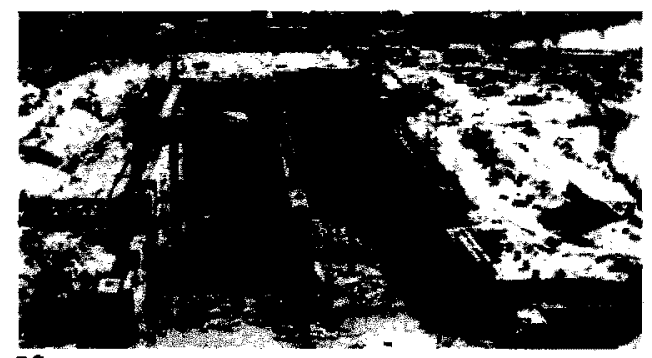

28.

These images denote rhythm, repetition, geometry and the fascist machine-body.

Image 24, from Triumph of the Will (Riefenstahl) offers an example of the geometric, regimented and machine-like appearance of the Nazi aesthetic. Image 22, an image of Nazi youths exercising, also suggests the pursuit of purity and strength in the body. This image is reminiscent of Hitler's speech comparing the ideal youth to Krupp steel. 


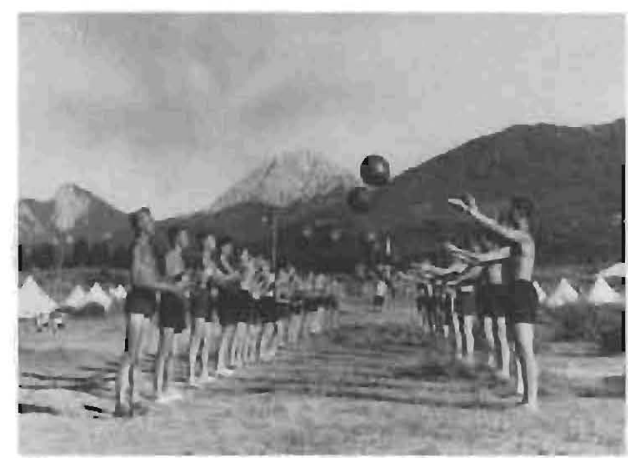

22.

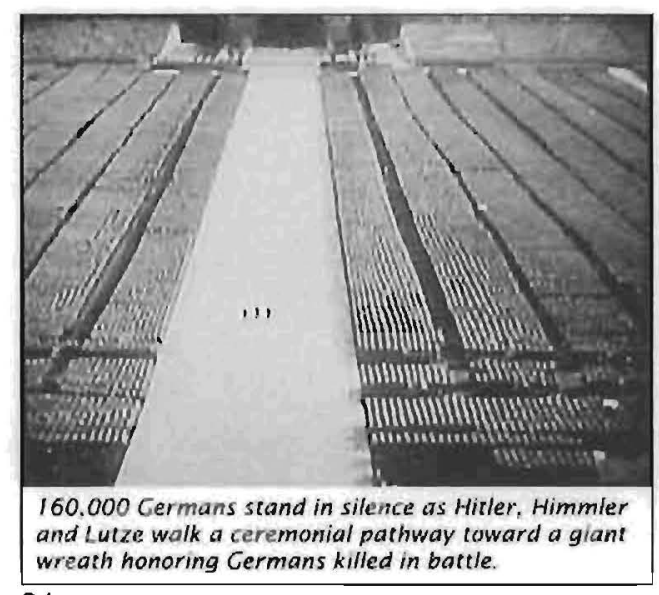

24.

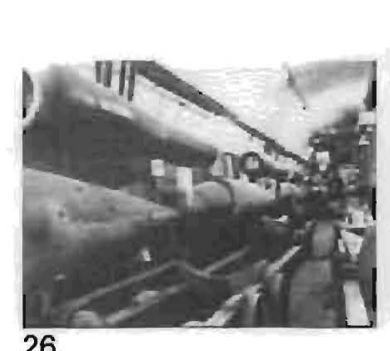

26.

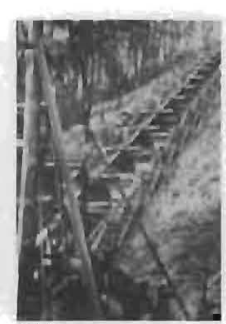

27.

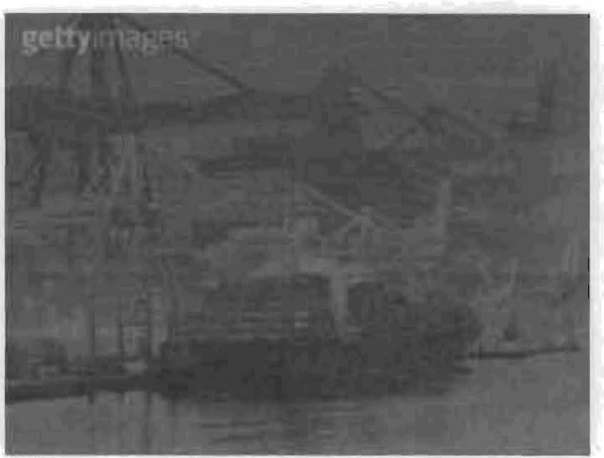

23.

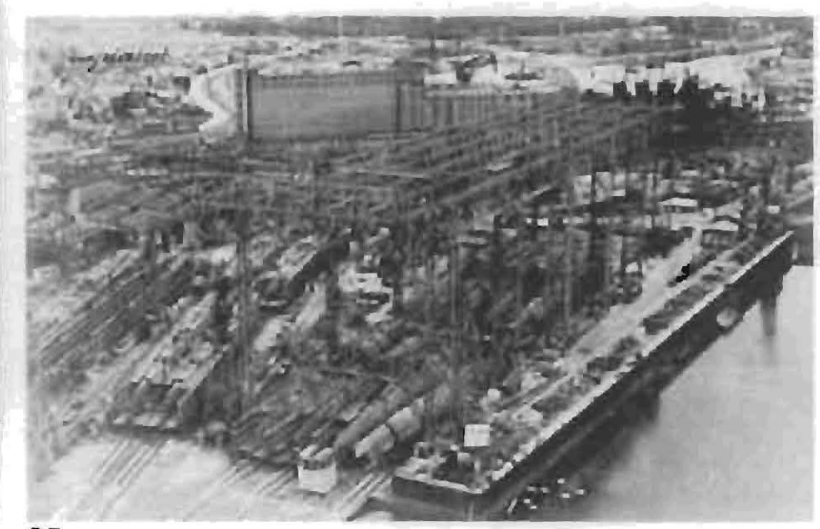

25.

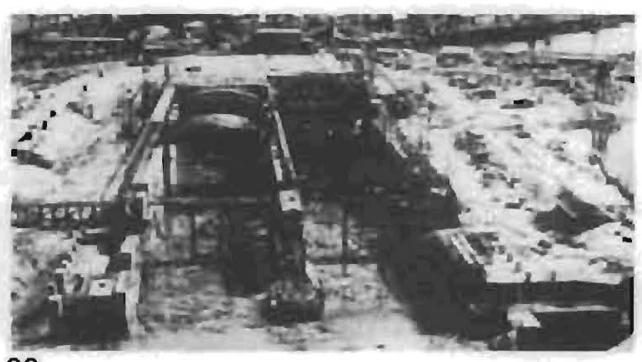

28.

These images denote rhythm, repetition, geometry and the fascist machine-body.

Image 24, from Triumph of the Will (Riefenstahl) offers an example of the geometric,

regimented and machine-like appearance of the Nazi aesthetic. Image 22, an image

of Nazi youths exercising, also suggests the pursuit of purity and strength in the body. This image is reminiscent of Hitler's speech comparing the ideal youth to Krupp steel. 


\section{Conclusion}

A reading of the machine and its relationship with the body is influenced by personal and historical contexts, spirituality and semiotics. Magnússon suggests historical readings that isolate from the greater historical understanding, but I believe this is unachievable - one's context, be it part of 'general history' or of a personal history, is unavoidable. I discovered this in my exploration of the flesh-body in relationship with the machine-body. My position on the matter was strongly influenced by my experiences in religion, academia and art making. The same can be said for the reading of my projects: the viewer is influenced by his or her experiences and contexts, and so the works continue to offer a discovery of ideas surrounding the machine and the body.

These projects are above all artistic investigations into the threat of the machine to the flesh-body and into connections between power and the Mechtech machine. The process of making involved rich exploration and self-discovery that I have described in this paper along with the ideas and theories that vitalized and influenced the works.

Barthes' commentary in The New Citroen on the mystical attraction to cars recalls the machine-human relationship with all of its historical and rhetorical readings:

I think that cars today are almost
the exact equivalent of the great
Gothic cathedrals: I mean the
supreme creation of an era, conceived
with passion by unknown artists, and
consumed in image if not in usage by
a whole population which appropriates 
them as a purely magical object (1).

It is the appropriation of a 'magical object' and the implications this has on the body that I have examined and to which I have reacted artistically in these pieces. My research was personal, technical, academic and aesthetic, and a wealth of work done by scholars and artists influenced my choices and ideas as well as imagery, sound and overall artistic response. With this response I strive to contribute to the fields to which I owe a great debt: aesthetics, philosophy and history. I hope that the ideas explored in these projects encourage further aesthetic responses and imaginative pursuits. 


\section{Bibliography and Filmography}

Armand, Louis. "Textual Machines: Joyce, Technology and The Avant-Garde": http://www.geocities.com/louis armand/avant garde.html

"Art as Spiritual Practice: Panel discussion with Alison Knowles, Eleanor Heartney, Meredith Monk, Linda Montano, and Erik Ehn; moderated by Bonnie Marranca." PAJ: A Journal of Performance and Art 24.3 (2002) 18-34.

Barthes, Roland. Mythologies. St. Albans: Paladin, 1972.

Image, Music, Text. New York: Hill, 1977.

Baudrillard, Jean. "Simulacra and Simulations": Jean Baudrillard, Selected Writings, ed. Mark Poster. Stanford: Stanford University Press, 1988, pp.166184.

Benjamin, Walter. "Work Of Art In The Age Of Mechanical Reproduction": Illuminations. 1969 pp 217-251

Berghaus, Gunter, ed. Fascism and Theatre: Comparative Studies on the Aesthetics and Politics of Performance in Europe. 1925-1945 Providence, R.I.: Berghan Books, 1996.

Bishop, Ryan and John Phillips. "Sighted Weapons and Modernist Opacity: Aesthetics, Poetics, Prosthetics." Boundry 2 Feb. 2002 157-179.

Bussey, Marcus. "Microvita and the Body Politic: Getting Mystery to Work for Us." http://www. metafuture.org: Articles by Colleagues.

Brolin, Brent C. The Failure of Modern Architecture. New York: Van Nostrand, 1976.

Brummett, Barry. Rhetoric of Machine Aesthetics. Westport, CT: Praeger, 1999.

Burstein, Jessica. "Waspish Segments: Lewis, Prosthesis, Fascism." Modernism/Modernity 4.21997 139-164.

Cheney, Sheldon and Martha Cheney. Art and the Machine. New York: Whittlesey House, 1936.

Chia, Robert C.H. "Diagrammatic Bodies." Organized Worlds: Explorations in Technology. London: Routledge, 1998. 
Chicago, III. : International Historic Films, [c. 1985]: Pre-war German

Featurettes: 1. Gestern und Heute $=$ Yesterday and today -2 . Drei Jahre

Adolf Hitler $=$ Three years of Adolf Hitler -3 . Ehre der Arbeit $=$ Honor of work - 4. Heer im werden = Becoming an army [An army is formed].

Coffman, Elizabeth. "Women in Motion: Loie Fuller and the "Interpenetration" of Art and Science." Camera Obscura 17.1 (2002) 73-105.

Dewey, John. Art as Experience. New York: Minton, Balch, 1934.

Douglas, Jack D, ed. Freedom and Tyranny: Social Problems in a Technological Society. New York, Alfred A. Knoff, Inc., 1970.

Dyens, Ollivier. Chair et metal: Metal and flesh : The Evolution of Man: Technology Takes Over ; translated by Evan J. Bibbee and Ollivier Dyens.

Ewen, Stuart and Elizabeth Ewen. Channels of Desire: Mass Images and the Shaping of American Consciousness. Minneapolois: U of Minnesota P, 1992.

Feenberg, Andrew. "Subversive Rationalization: Technology, Power and Democracy." Inquiry 353.4 (1992).

Florman, Samuel C. The Existential Pleasures of Engineering. $2^{\text {nd }}$ ed. New York: St. Martin's, 1994.

Fogu, Claudio. Book Review: "Futurism and Politics: Between Anarchist Rebellion and Fascist Reaction, 1909-1944": Modernism/Moderrity 4.1 (1997) 178-181.

Foster, Hal. "Prosthetic Gods." Modernism/Modernity 4.2 1997: 5-38.

Fotsch, Paul Mason. "The Building of a Superhighway Future at the New York World's Fair". Cultural Critique 48.1 (2001) 65-97.

Frick, Ron, Director. "Baraka." 1993.

Futurism. http://www.pitt.edu/ pugachev/greatwar/avant.htm

Fyfe, Nicholas R, ed. Images of the Street: Planning, Identity and Control in Public Space. London: Routledge, 1998.

Gentile, Emilio. "The Conquest of Modernity: From Modernist Nationalism to Fascism." Moderism/Modernity 1.3 1994: 55-87 
Gilliam, Terry, Director. "Brazil." Embassy International Pictures, 1985.

Guillerme, Jacques. "Design in the First Machine Age." Industrial Design: Reflection of a Century. Ed. Jocelyn de Noblet. Paris: Flammarion, 1993. 53 61.

Hansen, Anders et al. Mass Communication Research Methods. New York: New York University Press, 1998.

Hard, Mikael and Andreas Knie. "The Grammar of Technology: German and French Diesel Engineering, 1920-1940". Technology and Culture 40.1 (1999) 26-46.

Haug, Kate. "Femme Experimentale: Interviews with Carolee Schneemann, Barbara Hammer and Chick Strand." Wide Angle 20.1 1998: 1-9

Heidegger, Martin. The Question Concerning Technology, and Other Essays / Martin Heidegger ; translated and with an introduction by William Lovitt. New York : Harper \& Row Publishers, 1977.

Hong, Sungook. "Unfaithful Offspring?: Technologies and Their Trajectories". Perspectives on Science 6.3 (1998) 259-287.

Innis, Robert E. "Perception, Interpretation, and the Signs of Art." The Journal of Speculative Philosophy 15.12001 : 20-32.

Klock, Anja. "Of Cyborg Technologies and Fascistized Mermaids: Giannina Censi's Aerodanze in 1930s Italy." Theatre Journal 51.4 1999: $395-415$

Koepnick, Lutz P. "Fascist Aesthetics Revisited." The John Hopkins University Press 1999.

Léger, Fernand. "The Esthetics of the Machine." The Little Review. 9.3. (Spring, 1924): $45-49$.

Lewis, Robert. "Redesigning the Workplace: The North American Factory in the Interwar Period". Technology and Culture 42.4 (2001) 665-684.

Long, Fritz, Director. "Metropolis." 1926.

Magnússon, Sigurdur Gylfi. "The Singularization of History: Social History and Microhistory within the Postmodern State of Knowledge." Journal of Social History 36.3 (2003) 701-735.

Marianetti, Thomasso. "Multiplied Man and the Reign of the Machine." 
Mayall, W.H. Machines and Perception in Industrial Design. New York: Reinhold Book Corporation, 1968.

McHale, Brian. "Poetry as Prosthesis." Poetics Today 21.1 (2000) 1-32.

Mcluhan, Marshall, and Quentin Fiore. The Medium Is the Message: An Inventory of Effects. New York: Bantam, 1967.

McNeill, William H. Pursuit of Power. Chicago: University of Chicago Press, 1982.

Medina, Ada. "The Artist on Process and Ethics." Ethics \& The Environment 8.1 (2003)

Mumford, Lewis. Art and Technics. New York: Columbia UP, 1952.

Noble, David F. Progress without People : In Defense of Luddism. Chicago :

Charles H. Kerr Publishing Co.,1993.

Pearton, Maurice. Diplomacy, War and Technology Since 1830. London: Burnett Books Ltd, 1982.

Poggi, Christine. "Dreams of Metallized Flesh: Futurism and the Masculine Body." Modernism/Modernity 4.3 1997: 19 - 43.

Poster, Mark. "The Aesthetics of Distracting Media." The Culture Machine, 2001.

Rutsky, R.L. High Techne: Art and Technology from the Machine Aesthetic to the Posthuman. Minneapolis, MN: University of Minnesota Press, 1999.

Riefenstahl, Leni. Olympia, Pts. 1 and 2 : the film of the XI Olympic Games, Berlin 1936 / produced by Leni Riefenstahl ; music by Herbert Windt. New York : Phoenix Films ; Mississauga, On. : International Tele-Films Enterprise, 1938.

Triumph of the Will. Sandy Hook, CT: Video Yesteryear ; Mt. Albert, On. : Jeflyn Sales, 1936.

Sanders, Joe. "Tools/Mirrors: The Humanization of Machines." The Mechanical God: Machines in Science Fiction. Ed. Thomas P. Dunn and Richard D. Erlich. Westport, CT: Greenwood P, 1982. 167-76.

Sarti, Roland. Fascism and the Industrial Leadership in Italy, 1919-1940. Los 
Angeles: University of California Press, 1971.

Schnapp, Jeffrey T. "Between Fascism and Democracy: Gaetano CioccaBuilder, Inventor, Farmer, Engineer". Modernism/Modernity 2.3 (1995) 117 157.

"Propeller Talk." Modernism/Modernity 1.3 1994: 153-178.

Schuchard, Ronald. "Excavating the Imagination:Archival Research and the Digital Revolution". Libraries \& Culture 37.1 (2002) 57-63

Shanken, Edward A. "Tele-Agency: Telematics, Telerobotics, and the Art of Meaning." Art Journal 59.2 2000: 64-77.

Siebers, Tobin. "Hitler and the Tyranny of the Aesthetic." Philosophy and Literature 24.1 2000: 96-110

Starn, Randolf. "Truths in the Archives". Common Knowledge 8.2 (2002) 387401.

Stockton, Sharon. "Enineering Power: Hoover, Rand, Pound, and the Heroic Architect." The Duke University Press 200

Thomis, Malcolm I. Luddites : Machine-Breaking in Regency England. Newton Abbot, Eng.: David \& Charles, [1970].

Tomasulo, Frank P. "What Kind of Film History Do We Teach: The Introductory Survey Course as a Pedagogical Opportunity." Cinema Journal 41.1 2001: 110-114.

Vajda, Ferenc A. and Peter Dancey. German Aircraft Industry and Production 1933 - 1945. Bath: Bath Press, Ltd., 1998.

Van Doren, Harold. Industrial Design. New York: McGraw-Hill, 1940.

Waite, Geoff. "Nietzsche's Corps/e: Aesthetics, Politics, Prophecy or the Spectacular Technoculture of Everyday Life." Duke University Press, 1996

Williams, Roger. Politics and Technology. London: The Macmillan Press Ltd, 1971 .

Williams, Rosalind. "Lewis Mumford's Technics and Civilization". Technology and Culture 43.1 (2002) 139-149

Winston, Brian. "Documentary: How the Myth was Deconstructed." Wide 
Angle 21.2 1999: 71-86.

Yeh, Susan Fillin. Charles Sheeler and the Machine Age. Ph.D. dissertation, City University of New York, 1981. 


\section{Images Reference}

1. Petrou, Laurie: Industrial Strength, 2003

2. Ibid.

3. Riefenstahl, Leni. Triumph of the Will. Sandy Hook, CT: Video Yesteryear ; Mt. Albert, Ont. : Jeflyn Sales, 1936.

4. Getty Images, stock imagery:http://www.gettyone.com

5. Ibid.

6. Ibid.

7. Ibid.

8. Ibid.

9. Source Footage: Petrou, Laurie: Industrial Strength, 2003

10. Still: Petrou, The Gift The Threat, 2003.

11. Ibid.

12. Source Footage: Petrou, Laurie: Industrial Strength, 2003.

13. Places of World War II:http://unww.warplaces.net

14. Ibid.

15. Ibid.

16. Getty Images, stock imagery:Itttp://www.gettyone.com

17. Riefenstahl, Leni. Triumph of the Will. Sandy Hook, CT: Video Yesteryear ; Mt. Albert, Ont. : Jeflyn Sales, 1936.

18. Ibid.

19. Places of World War Il:http://www.warplaces.net

20. Ibid. 
21. Getty Images, stock imagery:http://www.gettyone.com

22. Ibid.

23. Ibid.

24. Riefenstahl, Leni. Triumph of the Will. Sandy Hook, CT: Video Yesteryear ; Mt. Albert, Ont. : Jeflyn Sales, 1936.

25. Places of World War II:http://www.warplaces.net/

26. Ibid.

27. Ibid.

28. Ibid. 